Natural Hazards and Earth System Sciences, 6, 41-48, 2006

SRef-ID: 1684-9981/nhess/2006-6-41

European Geosciences Union

(C) 2006 Author(s). This work is licensed

under a Creative Commons License.

\title{
Seismic vulnerability of dwellings at Sete Cidades Volcano (S. Miguel Island, Azores)
}

\author{
A. Gomes, J. L. Gaspar, and G. Queiroz \\ Centro de Vulcanologia e Avaliação de Riscos Geológicos Universidade dos Açores, Rua Mãe de Deus, 9500-801 Ponta \\ Delgada, Portugal
}

Received: 19 July 2005 - Revised: 7 October 2005 - Accepted: 7 October 2005 - Published: 10 January 2006

\begin{abstract}
Since the settlement of S. Miguel Island (Azores), in the XV century, several earthquakes caused important human losses and severe damages on the island. Sete Cidades Volcano area, located in the westernmost part of the island, was attained by strong seismic crises of tectonic and volcanic origin and major events reached a maximum historical intensity of IX (European Macroseismic Scale 1998) in this zone.

Aiming to evaluate the impact of a future major earthquakes, a field survey was carried out in ten parishes of Ponta Delgada County, located on the flanks of Sete Cidades volcano and inside it is caldera. A total of 7019 buildings were identified, being 4351 recognized as dwellings. The total number of inhabitants in the studied area is 11429 .

In this work, dwellings were classified according to their vulnerability to earthquakes (Classes A to F), using the structure types table of the EMS-98, adapted to the types of constructions made in the Azores. It was concluded that $76 \%$ (3306) of the houses belong to Class A, and 17\% (740) to Class B, which are the classes of higher vulnerability.

If the area is affected by a seismic event with intensity IX it is estimated, that $57 \%$ (2480) to $77 \%$ (3350) of the dwellings will partially or totally collapse and $15 \%$ (652) to $25 \%$ (1088) will need to be rehabilitated. In this scenario, considering the average of inhabitants per house for each parish, 82\% (9372) to $92 \%$ (10515) of the population will be affected. The number of deaths, injured and dislodged people will pose severe problems to the civil protection authorities and will cause social and economic disruption in the entire archipelago.
\end{abstract}

\section{Introduction}

The Azores archipelago is located in the Atlantic Ocean, between $37^{\circ}-40^{\circ} \mathrm{N}$ latitude and $25^{\circ}-31^{\circ} \mathrm{W}$ longitude and is formed by nine volcanic islands (Fig. 1).

Correspondence to: A. Gomes

(anagomes@notes.uac.pt)
The geological setting of the Azores region is dominated by the role of the American, Eurasian and African lithospheric plates fault boundaries (Searle, 1980). The most important tectonic structures recognised in the area are the MidAtlantic Ridge and the Terceira Rift (Fig. 2), that correspond to the main source of the seismic and volcanic activity registered in the region (Machado, 1959; Weston, 1964).

S. Miguel is the largest and most populated island of the Azores archipelago and is located in the eastern part of the Terceira Rift. The island is formed by several volcanic edifices placed along a general E-W direction (Fig. 3) and is crossed by NW-SE, NE-SW, WNW-ESE and E-W regional tectonic structures. Sete Cidades Volcano is an active central volcano with a summit caldera and is located in the westernmost part of S. Miguel, occupying an area of about $110 \mathrm{~km}^{2}$ and representing $15 \%$ of the total area of the island and has as highest point the Pico das Éguas, located at SE of caldera hole, with $874 \mathrm{~m}$.

\section{Seismic activity}

Since the settlement of the archipelago, in the 15th Century, many destructive earthquakes, volcanic eruptions and landslides were responsible for numerous victims and substantial damages. The most destructive earthquake occurred on S. Miguel Island on 22 October 1522, and destroyed the former capital of the Azores, Vila Franca do Campo, located in the south flank of Fogo Volcano. About 5000 people died due to the collapse of houses and the impact of two major landslides triggered by the event (e.g. Silveira, 2002; Marques et al., 2005). More recently, on 9 July 1998, a violent earthquake with is epicentre $7.5 \mathrm{~km} \mathrm{NE}$ of Faial Island attained a maximum seismic intensity of VIII/IX (MM-56), killing 9 persons and damaging many buildings and infrastructures (Senos et al., 1998).

In historical times, S. Miguel Island was affected by ten major earthquakes (Table 1). Apart from the events related with tectonic activity several important seismic swarms of 
Table 1. Earthquakes that affected S. Miguel Island with intensity equal or higher than VII (EMS-98) (adapted from Silveira, 2002). Legend: * seismic swarms associated with volcanic eruptions, ${ }^{+}$seismic swarms.

\begin{tabular}{|c|c|c|c|}
\hline Date & Intensity & More affected area & Consequences \\
\hline 22 October 1522 & $\mathrm{X}$ & Vila Franca do Campo & 5000 deaths. Huge destructions. \\
\hline June $1638^{*}$ & VI-VII & Várzea & Destruction of some houses. \\
\hline November-December $1713^{+}$ & IX & Mosteiros, Ginetes, Candelária & Destruction of houses and churches. \\
\hline July $1810^{*}$ & VII-VIII & W part of São Miguel Island & $\begin{array}{l}\text { Destruction of towers, facades and roof } \\
\text { of churches. }\end{array}$ \\
\hline June $1811^{*}$ & IX & W part of São Miguel Island & Destruction of many houses. \\
\hline 30 October $1848^{+}$ & VII-VIII & Várzea, Ginetes, Candelária, Feteiras & $\begin{array}{l}\text { Collapse of churches towers, partial or } \\
\text { total destruction of buildings. }\end{array}$ \\
\hline 16 April 1852 & VIII & Santana & Several deaths. \\
\hline 5 August 1932 & VIII & Povoação & $\begin{array}{l}\text { Several injuries. } 51 \% \text { dwellings de- } \\
\text { stroyed, } 3000 \text { people dislodged. }\end{array}$ \\
\hline 26 April 1935 & VIII-IX & Povoação & 1 death. $30 \%$ dwellings destroyed. \\
\hline 26 June 1952 & VIII & Ribeira Quente & Huge destructions. \\
\hline
\end{tabular}

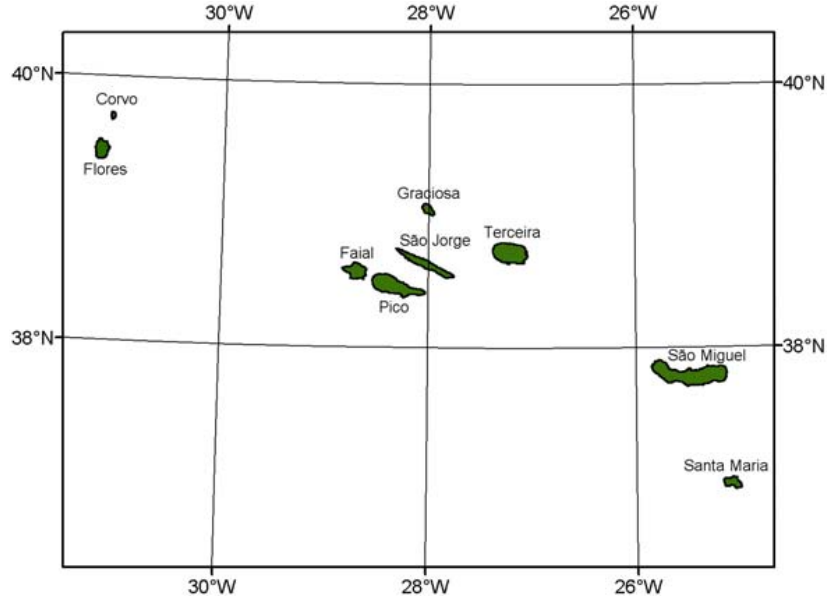

Fig. 1. Geographical location of the Azores archipelago.

volcanic origin also occurred on the island and in neighbouring submarine volcanic structures. Recent studies (Silveira et al., 2003) concluded that the maximum historical seismic intensity registered on the island was X (EMS-98), as result of the 1522 earthquake (Fig. 4).

In the Sete Cidades Volcano area the maximum historical seismic intensity reached IX (EMS-98) and was related with seismic crises associated to volcanic eruptions that occurred offshore, southwest (1713) and west (1811) of the island (Silveira et al., 2003). In the last 150 years there were no earthquakes with intensity equal or higher than VII, but at least seven earthquakes reached intensity VI (Table 2).

Instrumental seismicity record at the Azores started in the beginning of the XIX century but due to monitoring network constrains accurate data were not obtained before 1980 .

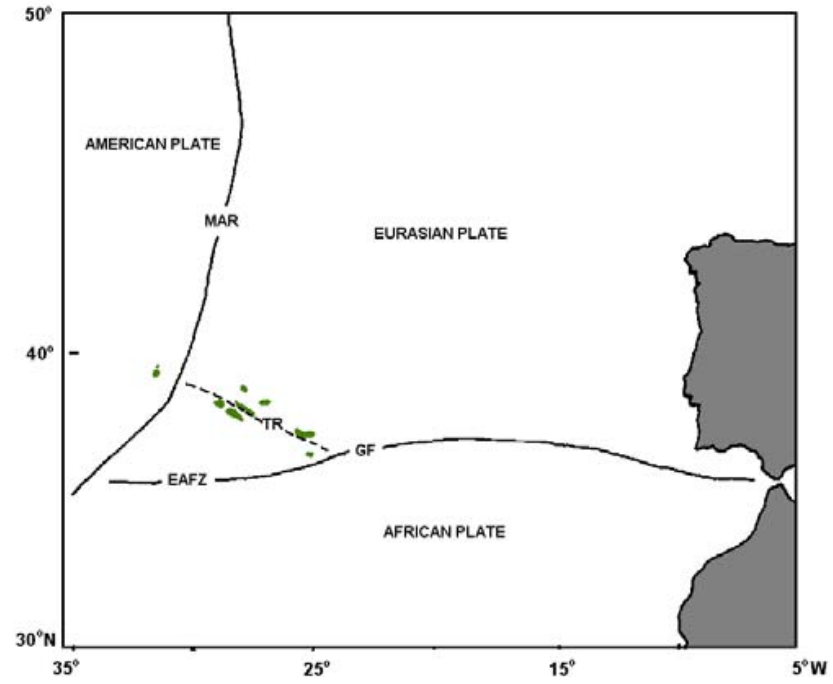

Fig. 2. Main tectonic structures in the Azores region. MAR - MidAtlantic Ridge; EAFZ - East Azores Fracture Zone; TR - Terceira Rift; GF - Gloria Fault (Gaspar et al., 1999)

Figure 5 shows the epicentre distribution of the best-located events in S. Miguel region for the last 20 years. It is clear that the central part of the island is the most seismically active, corresponding to the graben-like structure that extends between Fogo and Furnas volcanoes (Fig. 3). To the west, also the Sete Cidades volcano presents a significant level of seismic activity on land. All these main active central volcanoes and their related volcano-tectonic structures that extend into sea were the place of major earthquakes and seismic swarms in the past. Events occurring in any of these seismogenic zones can have an important impact in S. Miguel Island, namely in the Sete Cidades region, allowing to conclude that seismic hazard need to be considered during emergency planning and land use planning. 


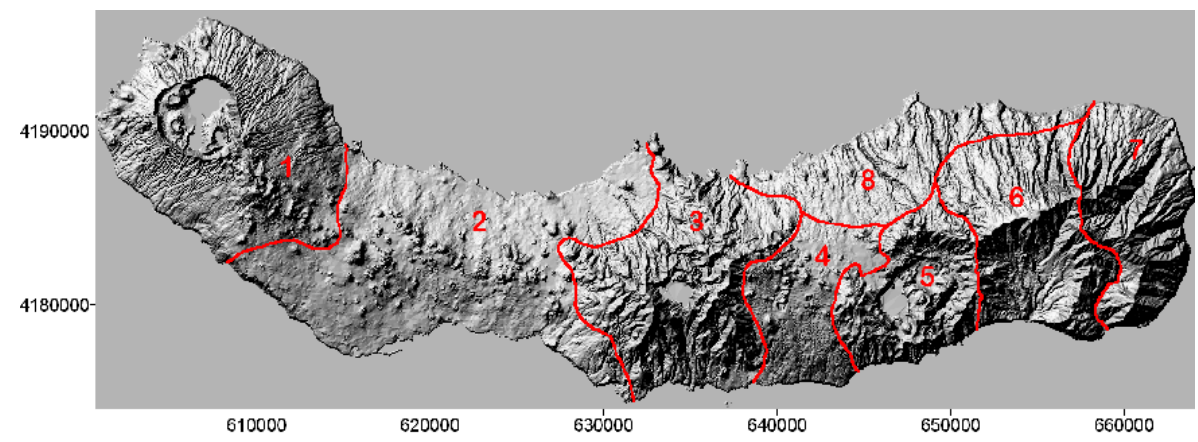

Fig. 3. Main morphological provinces of S. Miguel Island (Zbyszewski, 1961, Wallenstein, 1999): 1 - Sete Cidades Volcano; 2 - Picos Volcanic System; 3 - Fogo Volcano; 4 - Achada das Furnas Volcanic System; 5 - Furnas Volcano; 6 - Povoação Volcano; 7 - Nordeste Volcanic Complex; 8 - North Platform.

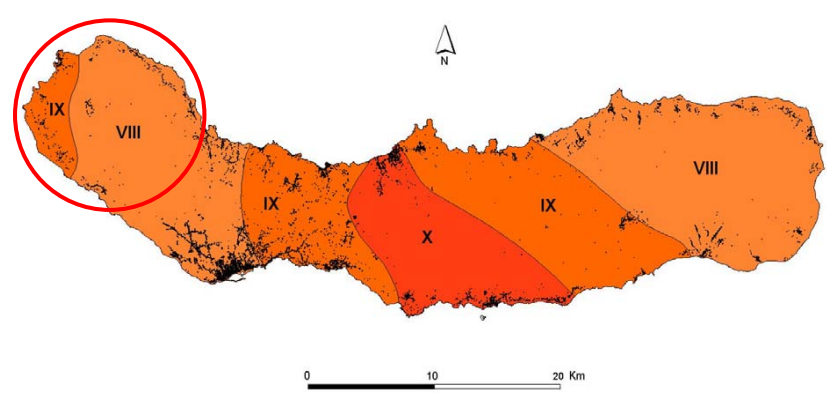

Fig. 4. Maximum historical seismic intensity map (EMS-98) of S. Miguel Island (Silveira et al., 2003). Legend: - study area.

\section{Vulnerability analysis}

\subsection{Field survey}

In order to evaluate the impact of a future major earthquake in the study area a detailed field survey was carried out in ten parishes of Ponta Delgada County, located in the flanks of Sete Cidades Volcano and inside it's caldera (Fig. 6). The 7019 buildings existent in the zone were individually visited, being 4351 classified as dwellings (Fig. 7). For each one a data form was filled comprising descriptive information about its geographical location and type of construction (Table 3). Such elements together with a photo from each house were inserted in the Azores Risk Assessment Database - AZORIS, built on a Geographical Information System (Gaspar et al., 2004) for vulnerability analysis.

\subsection{Dwellings classification}

Each dwelling was classified according to the European Macroseismic Scale 1998, that considers six vulnerability classes (A to F) taking into account a particular type of structure (Table 4). Class A is the most vulnerable and Class $F$ the least vulnerable one (Grünthal, 1998).

In order to apply this classification it was necessary to introduce minor changes in the proposed scheme due to some particularities commonly observed in the Azorean houses. In one way the adobe as a construction material is not used,
Table 2. Earthquakes that affected Sete Cidades area with intensity equal or higher than V-VI (EMS-98) (Gomes, 2003). Legend: * seismic swarms associated with volcanic eruptions, ${ }^{+}$seismic swarms.

\begin{tabular}{ll}
\hline Date & Intensity \\
\hline 22 October 1522 & VIII \\
June $1638^{*}$ & VI-VII \\
November-December $1713^{+}$ & IX \\
July $1810^{*}$ & VII-VIII \\
June $1811^{*}$ & IX \\
30 October $1848^{+}$ & VII-VIII \\
16 April 1852 & VII-VIII \\
5 August 1932 & V-VI \\
26 April 1935 & V-VI \\
26 June 1952 & V-VI \\
1 June 1965 & V-VI \\
17 June 1968 & VI \\
21 November 1988 & VI \\
21 July 1999 & V-VI \\
\hline
\end{tabular}

however the majority of the recent houses are built with blocks of concrete mixed with fine volcanic materials, such as basaltic lava and scoria fragments. Another point that came up during the field survey was related to the observation that several old dwellings had suffered recent interventions, in most of the cases to increase the number of rooms or even floors. For example, it was detected that some dwellings have sections where the external walls are made from lose or weakly cemented stones, while other sections are built with concrete blocks (Figs. 8 and 9). Houses in these conditions were considered to be of class A, due to the different behaviour of the structure in response to a seismic solicitation.

The integration of the collected field data with the EMS98 vulnerability classes allowed to conclude that around $76 \%$ (3306) of the houses belong to class A, 17\% (740) to class B, $7 \%$ (300) to class C and only $0.1 \%$ (5) to class D. 
Table 3. Guideline used in the field survey.

\begin{tabular}{|c|c|c|}
\hline Field information & Description & Options \\
\hline ID_BLD & Identification number for each building & Unique number ( 1 to $\mathrm{n}$ ) \\
\hline ID_GEOGRAPH & Identification string for each parish & Alphanumeric field \\
\hline STREET & Name of the street where the building is located & Alphanumeric field \\
\hline AD_NUMBER & House number & Alphanumeric field \\
\hline TYPE & Use of the building & $\begin{array}{l}\text { A - habitacional } \\
\text { B - public } \\
\text { C - comercial } \\
\text { D - monument } \\
\text { E - others } \\
\text { F - industry }\end{array}$ \\
\hline BASEMENT & Presence or absence of basement & Yes or no \\
\hline FLOORS & Number of floors & Numeric field \\
\hline ATTIC & Presence or absence of attic & Yes or no \\
\hline EXT_WALLS_MAT & Type of material used in the construction of the external walls & $\begin{array}{l}\text { A - irregular stone without bonding } \\
\text { B - bonded stone (cement or adobe) } \\
\text { C - bonded stone + plastered walls } \\
\text { D - bonded stone + net under + plastered walls } \\
\text { E - cement blocks } \\
\text { F - wood } \\
\text { G - metal } \\
\text { H - concrete } \\
\text { I - cement blocks + net under } \\
\text { J - stone blocks } \\
\text { K - stucco }\end{array}$ \\
\hline INT_WALLS_MAT & Type of material used in internal walls & $\begin{array}{l}\text { A - irregular stone without bonding } \\
\text { B - bonded stone (cement or adobe) } \\
\text { C - bonded stone + plastered walls } \\
\text { D - bonded stone + net under + plastered walls } \\
\text { E - cement blocks } \\
\text { F - wood } \\
\text { G - metal } \\
\text { H - concrete } \\
\text { I - cement blocks + net under } \\
\text { J - stone blocks } \\
\text { K - stucco }\end{array}$ \\
\hline BASEMENT_PAV & Type of material of the basement pavement & $\begin{array}{l}\text { A - wood } \\
\text { B - cement } \\
\text { C - soil } \\
\text { D - stone }\end{array}$ \\
\hline GR_FLOOR_PAV & Type of material of the ground floor pavement & $\begin{array}{l}\text { A - wood } \\
\text { B - cement } \\
\text { C - soil } \\
\text { D - stone }\end{array}$ \\
\hline ID_BLD & Identification number for each building & Unique number ( 1 to $\mathrm{n}$ ) \\
\hline FLOORS_PAV & Type of material of the different floors pavement & $\begin{array}{l}\text { A - wood } \\
\text { B - cement } \\
\text { D - stone }\end{array}$ \\
\hline ATTIC_PAV & Type of material of the attic pavement & $\begin{array}{l}\text { A - wood } \\
\text { B - cement } \\
\text { D - stone }\end{array}$ \\
\hline
\end{tabular}


Table 3. Continued.

\begin{tabular}{|c|c|c|}
\hline Field information & Description & Options \\
\hline ROOF_SUPP_MAT & Type of material of the tiles support in the roof & $\begin{array}{l}\text { A - wood } \\
\text { B - cement } \\
C \text { - metal }\end{array}$ \\
\hline ROOF_TILES_MAT & Type of tiles used in the roof & $\begin{array}{l}\text { A1 - regional clay } \\
\text { A2 - mainland clay } \\
\text { B - plastic } \\
\text { C - metal } \\
\text { D - fibro-cement } \\
\text { E - isothermal }\end{array}$ \\
\hline ROOF_INCL & Roof inclination & $\begin{array}{l}\mathrm{A}-\operatorname{gentle}\left(<20^{\circ}\right) \\
\mathrm{B}-\operatorname{normal}\left(20^{\circ} \text { to } 45^{\circ}\right) \\
\mathrm{C}-\operatorname{stressed}\left(>45^{\circ}\right)\end{array}$ \\
\hline ROOF_WATER_DS & Type of water drain system from the roof & $\begin{array}{l}\text { A - normal } \\
\text { A1 - normal + gutter } \\
\text { B1 - platband with internal plumbing } \\
\text { B2 - platband with external plumbing } \\
\text { B3 - platband with gargoyle } \\
\text { C - other }\end{array}$ \\
\hline WIN_MAT & Type of window material & $\begin{array}{l}\text { A - wood } \\
\text { B - metal } \\
\text { C - plastic }\end{array}$ \\
\hline WIN_PROT & Type of window protection & $\begin{array}{l}\text { A - without protection } \\
\text { B - jalousie } \\
\text { C1 - wooden internal jalousie (door shape) } \\
\text { C2 - wooden external jalousie (door shape) } \\
\text { D1 - metal internal jalousie (door shape) } \\
\text { D2 - metal external jalousie (door shape) }\end{array}$ \\
\hline DOOR_MAT & Type of door material & $\begin{array}{l}\text { A - wood } \\
\text { B - metal }\end{array}$ \\
\hline DOOR_PROT & Type of protection for door with top or lateral windows & $\begin{array}{l}\text { A - wood } \\
\text { B - metal }\end{array}$ \\
\hline OBS & Additional elements about the building & Alphanumeric field \\
\hline ID_PHOTO & Identification of the building photo & Alphanumeric field \\
\hline
\end{tabular}

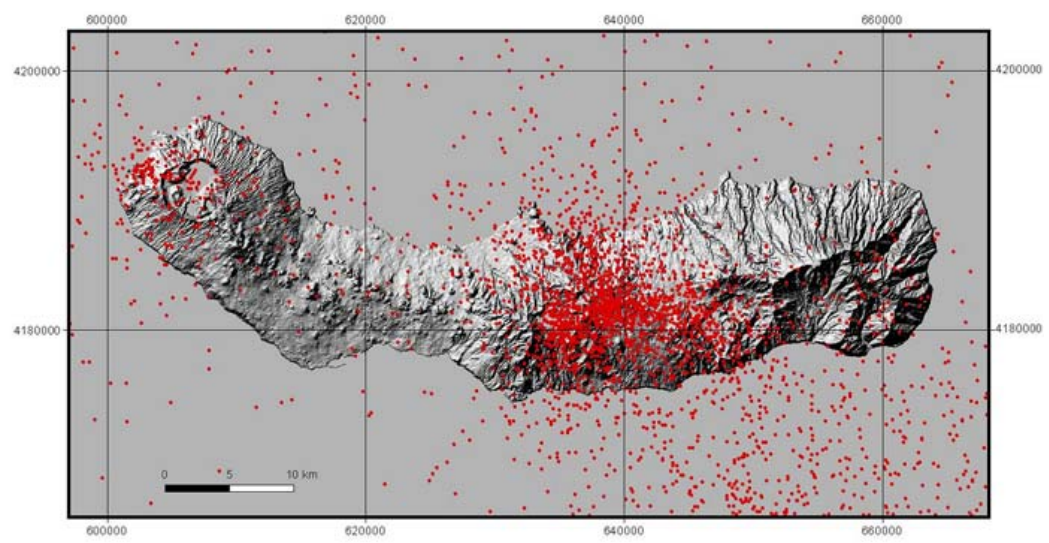

Fig. 5. Map of the seismic activity in S. Miguel Island in the last 20 years (data from SIVISA, 2004). 
Table 4. Classification of buildings according to vulnerability (Grünthal, 1998).

\begin{tabular}{|c|c|c|c|c|c|c|c|}
\hline \multirow{2}{*}{\multicolumn{2}{|c|}{ Type of Structure }} & \multicolumn{6}{|c|}{ Vulnerability Class } \\
\hline & & A & B & C & $\mathrm{D}$ & $E$ & $\mathrm{~F}$ \\
\hline \multirow{7}{*}{ 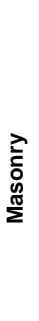 } & Rubble stone, fieldstone & - & & & & & \\
\hline & Adobe (earth brick) & 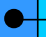 & $\rightarrow$ & & & & \\
\hline & Simple stone & 4 & 0 & & & & \\
\hline & Massive stone & & 4 & 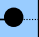 & $\rightarrow$ & & \\
\hline & $\begin{array}{l}\text { Unreinforced, with manufactured stone } \\
\text { units }\end{array}$ & 4 & O & $\rightarrow$ & & & \\
\hline & Unreinforced, with RC floors & & 4 & 0 & $\rightarrow$ & & \\
\hline & Reinforced or confined & & & 4 & 0 & $\rightarrow$ & \\
\hline \multirow{6}{*}{ 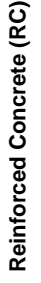 } & $\begin{array}{l}\text { Frame without earthquake-resistante } \\
\text { desing (ERD) }\end{array}$ & 4 & & & $\rightarrow$ & & \\
\hline & Frame with moderate level of ERD & & 4 & & - & $\rightarrow$ & \\
\hline & Frame with high level of ERD & & & 4 & - & - & $\rightarrow$ \\
\hline & Walls without ERD & & 4 & - & $\rightarrow$ & & \\
\hline & Walls with moderate level of ERD & & & 4 & - & $\rightarrow$ & \\
\hline & Walls with high level of ERD & & & & 4 & 0 & $\rightarrow$ \\
\hline $\begin{array}{l}\overline{\bar{d}} \\
\bar{\omega}\end{array}$ & Steel structures & & & 4 & & & $>$ \\
\hline : & Timber structures & & 4 & & & $\rightarrow$ & \\
\hline
\end{tabular}

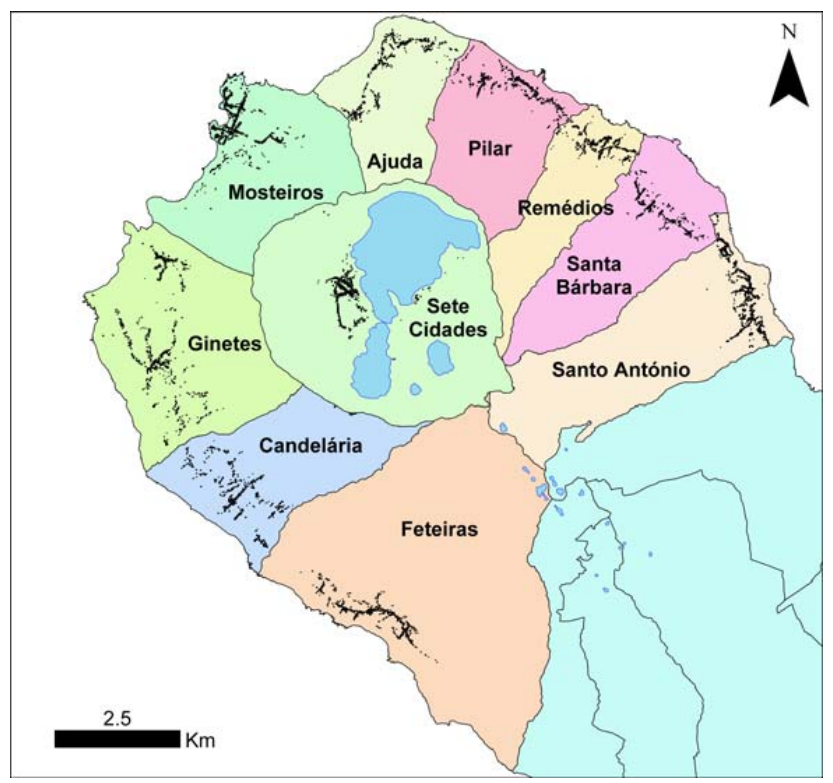

Fig. 6. Location of the ten parishes of Ponta Delgada County considered in this work.

\section{Discussion}

As it was observed following the 9 July 1998 earthquake, in Faial Island, houses with damages less than $20 \%$, corresponding to grades 1 and 2 of the EMS-98, only needed slight reparations. Dwellings with damages between 20 and $50 \%$ (grade 3) were rehabilitated, and new houses were built when the observed damages were higher than $50 \%$ (grades 4 and 5).

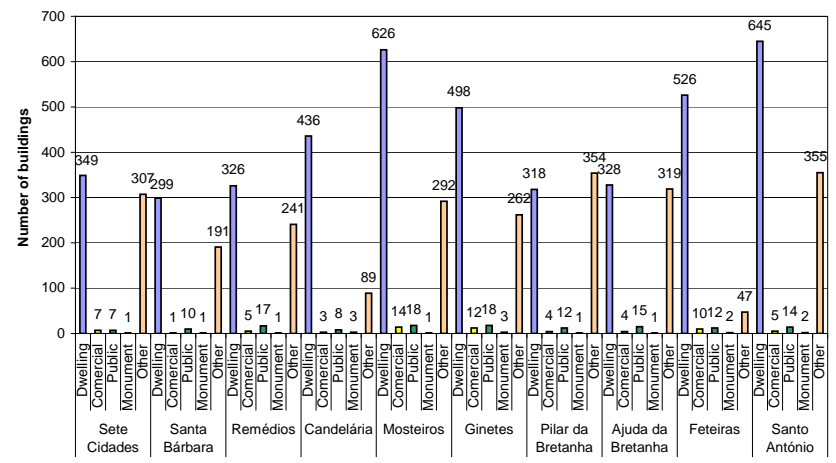

Fig. 7. Number of buildings by type of use in each parish (Gomes, 2003). Legend: A - Dwelling; B - Other; C - Commercial; D Public; E - Monument.

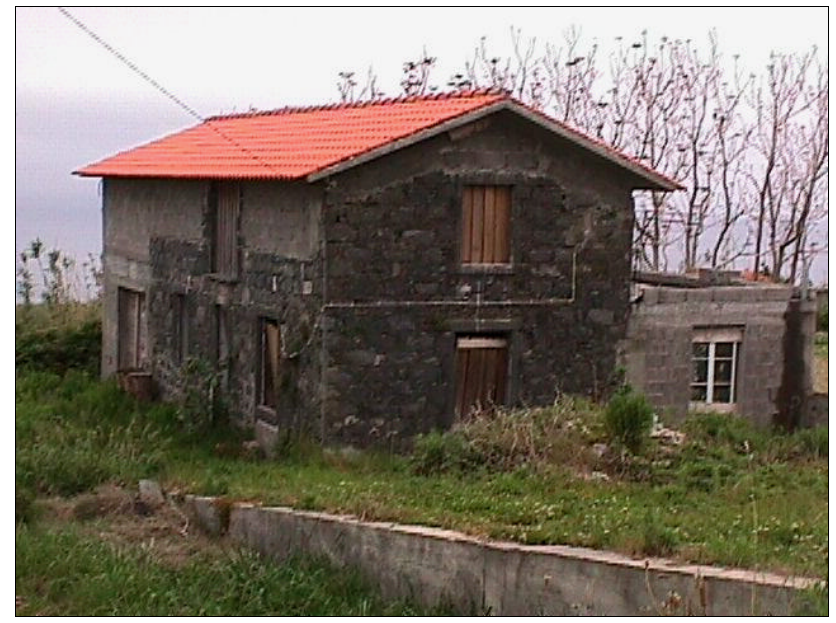

Fig. 8. Dwelling with external walls in stone and in concrete blocks.

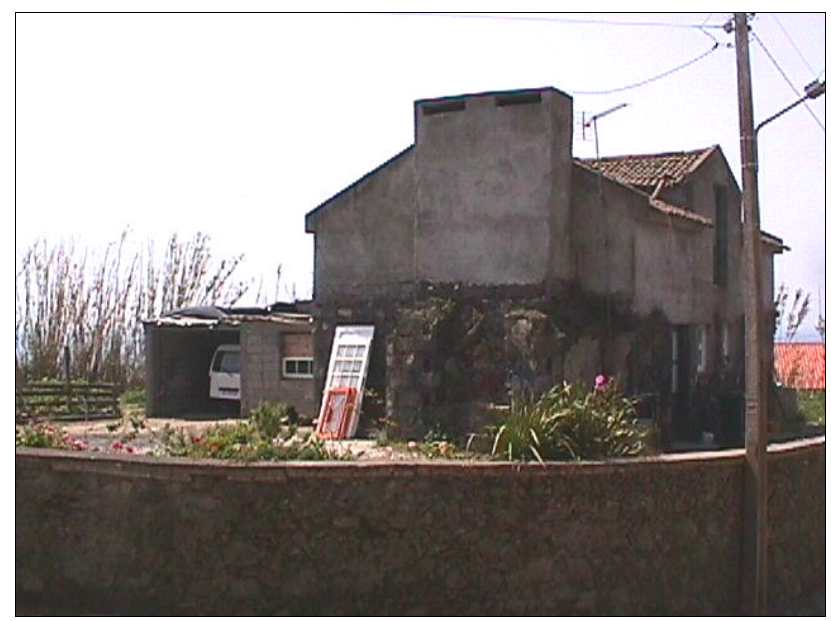

Fig. 9. Dwelling with external walls both in stone and in concrete blocks.

Appling the same criteria to analyse the impact of a future destructive earthquake in Sete Cidades region, and taking into account the type and percentage of damages admitted 
Table 5. Calculation of dwellings damages and affected population for different seismic intensity values (EMS-98).

\begin{tabular}{|c|c|c|c|c|c|c|c|c|c|c|}
\hline \multirow{3}{*}{ Intensity } & \multicolumn{8}{|c|}{ Dwellings for each grade of damage } & \multirow{2}{*}{\multicolumn{2}{|c|}{ Affected population }} \\
\hline & \multicolumn{2}{|c|}{0} & \multicolumn{2}{|c|}{1 and 2} & \multicolumn{2}{|c|}{3} & \multicolumn{2}{|c|}{4 and 5} & & \\
\hline & $\%$ & Number & $\%$ & Number & $\%$ & Number & $\%$ & Number & $\%$ & Number \\
\hline $\mathrm{V}$ & 86 to 100 & 3741 to 4351 & 0 to 14 & 0 to 609 & - & - & - & - & - & - \\
\hline $\mathrm{VI}$ & 34 to 86 & 1479 to 3741 & 14 to 66 & 609 to 2872 & - & - & - & - & - & - \\
\hline VII & 6 to 15 & 261 to 653 & 38 to 74 & 1653 to 3220 & 11 to 44 & 479 to 1914 & 0 to 11 & 0 to 479 & 11 to 56 & 1257 to 6400 \\
\hline VIII & 2 to 6 & 87 to 261 & 17 to 37 & 740 to 1610 & 26 to 45 & 1131 to 1958 & 11 to 55 & 479 to 2393 & 57 to 81 & 6515 to 9257 \\
\hline IX & 1 to 2 & 44 to 87 & 7 to 16 & 305 to 696 & 15 to 25 & 653 to 1088 & 57 to 77 & 2480 to 3350 & 82 to 92 & 9372 to 10515 \\
\hline
\end{tabular}

Table 6. Present-day dwellings damages and affected population considering the 1811 seismic crisis scenario.

\begin{tabular}{|c|c|c|c|c|c|c|c|c|c|c|c|}
\hline \multirow{3}{*}{ Parish } & \multirow{3}{*}{$\begin{array}{c}1811 \text { seismic } \\
\text { intensities }\end{array}$} & \multicolumn{8}{|c|}{ Dwellings for each grade of damage } & \multirow{2}{*}{\multicolumn{2}{|c|}{ Affected population }} \\
\hline & & \multicolumn{2}{|c|}{0} & \multicolumn{2}{|c|}{1 and 2} & \multicolumn{2}{|c|}{3} & \multicolumn{2}{|c|}{4 and 5} & & \\
\hline & & $\%$ & Number & $\%$ & Number & $\%$ & Number & $\%$ & Number & $\%$ & Number \\
\hline Pilar & VIII & 2 to 5 & 5 to 15 & 14 to 35 & 43 to 112 & 26 to 48 & 83 to 152 & 12 to 59 & 38 to 186 & 60 to 85 & 390 to 551 \\
\hline Ajuda & VIII & 2 to 5 & 6 to 16 & 14 to 34 & 46 to 110 & 24 to 49 & 80 to 160 & 12 to 60 & 41 to 197 & 61 to 84 & 420 to 576 \\
\hline Remédios & VIII & 2 to 6 & 6 to 18 & 15 to 35 & 50 to 113 & 24 to 48 & 79 to 155 & 12 to 58 & 39 to 190 & 60 to 83 & 596 to 823 \\
\hline Santa Bárbara & VIII & 2 to 6 & 6 to 17 & 16 to 38 & 48 to 114 & 27 to 45 & 81 to 135 & 11 to 55 & 33 to 164 & 56 to 82 & 494 to 722 \\
\hline Sete Cidades & VIII & 2 to 6 & 8 to 22 & 18 to 48 & 62 to 166 & 35 to 38 & 122 to 132 & 8 to 45 & 29 to 158 & 46 to 80 & 395 to 687 \\
\hline Feteiras & VIII & 2 to 6 & 11 to 32 & 17 to 33 & 87 to 176 & 22 to 48 & 116 to 253 & 12 to 59 & 65 to 311 & 61 to 81 & 1039 to 1388 \\
\hline Santo António & VIII & 3 to 8 & 17 to 49 & 21 to 38 & 133 to 248 & 24 to 43 & 155 to 278 & 11 to 53 & 70 to 341 & 54 to 77 & 1082 to 1538 \\
\hline Mosteiros & IX & 1 to 2 & 5 to 12 & 6 to 15 & 41 to 95 & 14 to 29 & 89 to 182 & 54 to 79 & 337 to 492 & 54 to 82 & 643 to 981 \\
\hline Candelária & TX & 1 to 2 & 4 to 10 & 8 to 18 & 34 to 78 & 16 to 22 & 70 to 98 & 57 to 75 & 250 to 328 & 57 to 79 & 679 to 937 \\
\hline Ginetes & IX & 1 to 2 & 4 to 9 & 7 to 15 & 33 to 73 & 14 to 23 & 69 to 116 & 60 to 79 & 300 to 392 & 60 to 83 & 764 to 1049 \\
\hline
\end{tabular}

for each seismic intensity by the EMS-98, it was estimated the total number of houses that might be affected and their respective grades of damage (Table 5). If the whole area is affected by a seismic event with intensity IX, 57\% (2480) to $77 \%$ (3350) of the dwellings will partially or totally collapse and $15 \%$ (652) to $25 \%$ (1088) will need to be rehabilitated. In such a scenario, considering the 2001 census and the average of inhabitants per house for each parish, 82\% (9372) to $92 \%(10515)$ of the population will be affected (Table 5).

The application of this expedite method allows to create different scenarios that can be used to mitigate the seismic risk. As an example, it was studied the present-day impact of an event similar to the one that occurred in 1811, related with the seismic swarm that accompanied a submarine volcanic eruption, a few miles west of S. Miguel Island. In this situation three parishes (Candelária, Ginetes and Mosteiros) become affected with intensity IX (EMS-98) while the remaining area face intensity VIII (Table 6). The obtained results show that $28 \%$ (1202) to $63 \%$ (2759) of the dwellings will partially or totally collapse and 22\% (944) to $38 \%$ (1661) will need to be rehabilitated. Under these circumstances $57 \%$ (6502) to $81 \%$ (9252) of the population will be affected.

\section{Conclusions}

Taking into account historical records and instrumental seismic data it is clear that seismic hazard at S. Miguel Island is considerably high and justify the application of expedite methods to develop scenarios useful for risk mitigation. A major earthquake should be expected to occur in a near future and appropriate preventive measures need to be implemented to minimize its impact.
Dwellings in the Sete Cidades area were classified according to their vulnerability taking into account the criteria defined by the European Macroseismic Scale 1998. A detailed field survey allowed to verify that from a total of 4351 houses, around $76 \%$ belong to class A, $17 \%$ to class B, $7 \%$ to class $\mathrm{C}$ and $0.1 \%$ to class $\mathrm{D}$. This fact emphasizes the overall high vulnerability of the dwellings and constitutes an important fragility that should be inverted through the application of appropriate political measures.

The obtained data was used to create different scenarios for emergency planning considering the percentage of damages estimated for each seismic intensity, as it is proposed by the EMS-98. The Sete Cidades case studied allowed concluding that if the entire region faces a strong earthquake, seismic intensities can reach at least IX (EMS-98) and, therefore, a huge level of damages will occur. More than $50 \%$ of the houses may be totally or partially destroyed and between 6500 to 10500 people will be directly affected. Such degree of destruction and the number of deaths, injured and dislodged people will cause an important social and economic disruption that can prevail for several years.

Acknowledgements. This work was supported by Project CARIGE "Carta de Riscos Geológicos da Região Autónoma dos Açores", supported by the Azores Regional Government, and Project EXPLORIS "Explosive eruption risk and decision support for EU populations threatened by volcanoes" contract no. EVR1-CT-200240026.

Edited by: T. Glade

Reviewed by: K.-G. Hinzen and another referee 


\section{References}

Gaspar, J. L., Goulart, C., Queiroz, G., Silveira, D., and Gomes, A.: Dynamic structure and data sets of a GIS database for geological risk analysis in the Azores volcanic islands, Nat. Haz. Earth Syst. Sci., 4, 1-10, 2004,

\section{SRef-ID: 1684-9981/nhess/2004-4-1.}

Gaspar, J. L., Trota, A., Queiroz, G., Ferreira, T., and Alves, P.: Plano Municipal de Emergência da Vila do Porto, ilha de Santa Maria, Centro de Vulcanologia e Avaliação de Riscos Geológicos, Universidade dos Açores, 1999.

Gomes, A.: Contribuição para o estudo dos riscos geológicos no Vulcão das Sete Cidades (S. Miguel, Açores), Master Thesis on Volcanology and Geological Risks, Universidade dos Açores, 129 pp., 2003.

Grünthal, G. (ed.): European Macroseismic Scale 1998, Cahiers du Centre Européen de Géodynamique et de Séismologie, 15, 1-99, 1998.

Machado, F.: Submarine pits of the Azores plateau, Bulletin Volcanologique, Série II, Tome XXI, 108-116, 1959.

Marques, R., Gaspar, J. L., and Zêzere, J. L.: Reconstruction of the 1522 earthquake-induced landslide of Vila Franca do Campo (S. Miguel, Azores), Eng. Geology, in press, 2005.

Queiroz, G.: Vulcão das Sete Cidades (S. Miguel, Açores), História eruptiva e avaliação do hazard, $\mathrm{PhD}$ Thesis on Volcanology, Universidade dos Açores, 226, 1997.
Searle, R.: Tectonic pattern of the Azores spreading centre and triple junction, Earth Planet. Sci. Lett., 51, 415-434, 1980.

Senos, M. L., Gaspar, J. L., Cruz, J., Ferreira, T., Nunes, J. C., Pacheco, J., Alves, P., Queiroz, G., Dessai, P., Coutinho, R., Vales, D., and Carrilho, F.: O terramoto do Faial de 9 de Julho de 1998, Proceedings do "1o Simpósio de Meteorologia e Geofísica da APMG”, 61-68, 1998.

Silveira, D.: Caracterização da sismicidade histórica da ilha de São Miguel com base na reinterpretação de dados de macrossísmica: contribuição para a avaliação do risco sísmico, Master Thesis on Volcanology and Geological Risks, Universidade dos Açores, 149,2002

Silveira, D., Gaspar, J. L., Ferreira, T., and Queiroz, G.: Reassessment of the historical seismic activity with major impact on $\mathrm{S}$. Miguel Island (Azores), Nat. Hazards Earth Syst. Sci., 3, 615623, 2003,

SRef-ID: 1684-9981/nhess/2003-3-615.

Wallenstein, N.: Estudo da história recente do comportamento eruptivo do Vulcão do Fogo (S. Miguel, Açores), Avaliação preliminar do hazard, $\mathrm{PhD}$ Thesis on Volcanology, Universidade dos Açores, 266, 1999.

Weston, F.: List of recorded volcanic eruptions in the Azores with brief reports, Bol. Mus. Lab. Min. Geol. Fac. Ciências de Lisboa, 10, 3-18, 1964.

Zbyszewski, G.: Étude géologique de l'île de S. Miguel (Açores), Comunicações dos Serviços Geológicos de Portugal, tomo XLV, 79, 1961 